side. Let the side $z_{1} z_{2}$ be the $x$-axis. The equation of the tangent parallel to this axis is

$$
y=\frac{\mu_{1}+\mu_{2}}{\mu_{1}+\mu_{2}+\mu_{3}} y_{3},
$$

with similar equations of the tangents parallel to the other two sides. Let $\mu_{3}$ be negative. The points of contact with the sides $z_{1} z_{3}$ and $z_{2} z_{3}$ lie between the $x$-axis and the parallel tangent or outside them according as

$$
\mu_{1}+\mu_{2}+\mu_{3} \lessgtr 0 \text {, }
$$

and the conic is accordingly an ellipse or hyperbola.

Hence if all the powers be positive $\varphi=0$ is an ellipse. If one of the powers be negative it is an ellipse, parabola or hyperbola according as their sum is less than, equal to or greater than zero. If two of the powers be negative it is an ellipse, parabola or hyperbola according as their sum is greater than, equal to or less than zero. In particular if $\mu_{1}+\mu_{3}=0$ the side $z_{1} z_{3}$ is an asymptote. If $\mu_{1}=\mu_{2}=-\mu_{3}$ the sides $z_{1} z_{3}$ and $z_{2} z_{3}$ are asymptotes. If in addition the triangle $z_{1} z_{2} z_{3}$ is isosceles having its vertex at $z_{3}$, the circle having $z_{3}$ for its center and passing through $z_{1}$ and $z_{2}$ passes through the foci of $\varphi=0$, for the altitude and half base of this triangle are the major and minor axes respectively.

UNIVERSITY OF VIRGINIA, May 1, 1919.

\title{
MORITZ CANTOR, THE HISTORIAN OF MATHEMATICS.
}

BY PROFESSOR FLORIAN CAJORI.

(Read before the San Francisco Section of the American Mathematical Society June 17, 1920.)

Professon Moritz Cantor died at Heidelberg on April 10, 1920 , in his ninety-first year, three days after the death of his only son. Considering his own long career and that of many other mathematicians, he could well remark on his eightieth birthday, "Die Mathematik gehört nicht gerade zu den ungesunden Handwerken."* His literary activity ex-

* Felix Müller, Der Mathematische Sternenhimmel des Jahres 1811, Leipzig und Berlin, 1911, p. 7. 
tended over a very long period, from 1851 to 1908 . He has been known for many years as the leading writer of his time on the general history of mathematics. In the nineteenth century, his Vorlesungen über Geschichte der Mathematik came to be regarded as the fullest and the most reliable general source of historical information on our science. Before his time the outstanding historian of mathematics had been the Frenchman, J. E. Montucla, whose history appeared in 1758 in two volumes, and in 1799-1802 in four volumes (completed with the cooperation of the astronomer J. J. Lalande). Moritz Cantor is the Montucla of the nineteenth century.

Cantor was born in Mannheim on August 23, 1829. In 1848 he attended the University of Heidelberg and later studied at Göttingen under K. F. Gauss and W. Weber.* In the fall of 1851 he took his doctorate at Heidelberg, presenting a thesis "Ueber ein wenig gebrauchtes Koordinatensystem," which as yet disclosed no interest in that field of research which later he cultivated so assiduously. Curtze adds: "Before he came to devote himself wholly to an academic career-a state's examination he never took-he went to Berlin for study, where he attended especially the lectures of Lejeune-Dirichlet." We have seen nothing to indicate that Cantor had been in contact with, or had been influenced by, the Heidelberg privat-docent and Lyceum professor, Arthur Arneth, the author of the Geschichte der reinen Mathematik, Stuttgart, 1852. $\dagger$ Of three or more articles which Cantor prepared in the next few years, only one short paper of a dozen pages is historical, viz., "Ueber die Einführung unserer Ziffern," 1856, published in the Zeitschrift für Mathematik und Physik. What was the circumstance that induced him to choose the history of mathematics as his life work? The present writer visited him on May 2, 1915 , and, in the course of conversation, asked him this very question. He replied that he prepared a paper on Ramus, Stifel and Cardan, $\ddagger$ which he read at a scientific meeting at

* For facts of his early life we depend upon an article by Maximilian Curtze in Bibliotheca Mathematica, ser. 3, vol. 1, Leipzig, 1900, pp. 227231.

$\dagger$ See M. Cantor's sketch of Arneth in the Allgemeine Deutsche Biographie, Leipzig, 1875.

† The article is "Petrus Ramus, Michael Stifel, Hieronymus Cardanus, drei mathematische Charakterbilder aus dem 16. Jahrhundert," Zeitschrift für Mathematik und Physik, vol. 2, 1857, pp. 353-367. 
Bonn and which was so well received that he felt encouraged to continue in historical work. Thus, a little praise proved in his case a deciding factor. Perhaps this experience led him later in life to deal leniently with the shortcomings of young writers and to show generous appreciation of any merit he was able to discover. Soon after, Cantor went to Paris and there met Michel Chasles and Joseph Bertrand. Chasles had published in 1837 his Aperçu Historique and enjoyed wide celebrity as the historian of geometry. He paid much attention to the young German and secured the publication in the Comptes Rendus of a historical note prepared by the latter. Cantor prided himself on the command that he acquired of the French language. He told the writer that after delivering an address in French at the Mathematical Congress of 1900 in Paris, two Frenchmen came up and asked him to decide a bet: One Frenchman arguing that no foreigner could learn to speak French so well; the other claiming that Cantor was a German living in Germany.

It was in 1863 that Cantor's first important historical book appeared, his Mathematische Beiträge zum Kulturleben der Völker, which attracted wide attention, and was both praised and criticized. It championed an oft-repeated but seldom realized ideal in the writing of the history of our science, namely, the exhibition of the place of mathematics in the cultural life of a people and in the intercourse between nations. In this book, and in the first, and part of the second, volumes of the Vorlesungen, Cantor kept this goal in view. In the discussion of arithmetic and the history of our numerals, as given in his Beiträge, Cantor was influenced not only by the French writers M. Chasles, A. J. H. Vincent, and Henri Martin, but also by the early papers of the German G. Friedlein. Later Cantor was in frequent correspondence with the great French historian, Paul Tannery.

In 1864 Maximilian Curtze of the gymnasium of Thorn sought the assistance of Cantor in the interpretation of passages in a medieval manuscript. Thus began a friendship which continued unbroken until the death of Curtze in 1903.

Having been privat-docent at Heidelberg since 1853, Cantor advanced in 1863 to the position of professor extraordinary of mathematies. Probably about this time he began to give lectures on the history of mathematics. These lecture 
courses extended sometimes over a period of three semesters.* According to Curtze, among those attending Cantor's lectures was Siegmund Günther, who is well-known as a historian of science. $\dagger$

For the next ten or twelve years Cantor's publications were mainly historical. We make special mention of his Euklid und sein Jahrhundert (1867) and his Die Römischen Agrimensoren (1875). These served as preliminary researches for his great work, the Vorlesungen über Geschichte der Mathematik, the first volume of which appeared in 1880 when he was over fifty years of age. His previous studies, extending over a period of a quarter of a century, had been preparatory for this standard work. In entering upon this gigantic task he showed a predilection far remote from that of Paul Tannery. Cantor was writing a general history, while Tannery preferred to exercise his genius in elucidating special fields and special periods. A second edition of this first volume appeared in 1894, a third in 1907. Twelve years elapsed between the first and second volumes of the Vorlesungen. This second volume (1892) carried the history from the year 1200 to the year 1668, when Leibniz and Newton were just entering upon their great careers of discovery. A second edition of the second volume appeared in 1899. During the years 1894-1898 were published successive parts of the third volume which carries the history down to 1758 , the time of the rise of Lagrange in the mathematical firmament. A second edition was brought out in 1901. These three great volumes enjoyed an enthusiastic reception. In 1898 Professor George A. Gibson of Glasgow only moderately expressed the feeling of his time when he said: $\ddagger$ "That the labour involved in collecting material and in reducing it to shape would be great, Mr. Cantor doubtless knew well; but in all probability his most liberal estimate of the demands likely to be made upon his energies has been far exceeded; in any case, one can readily understand the feelings of satisfaction with which he writes the preface to the concluding volume. It hardly requires to be stated that this history is certain to remain for many years the standard work on the

* Zeitschrift für Mathematischen und Naturwissenschaftlichen Unterricht (Schotten), vol. 43, Leipzig und Berlin, 1912, p. 526.

$\dagger$ Bibliotheca Mathematica, ser. 3, vol. 1, p. 229.

$\ddagger$ Proceedings of the Edinburgh Mathematical Society, vol. 17, 1898, p. 9. 
subject with which it deals; in completeness, in accuracy, in clearness of arrangement, it stands unrivalled, and for the period which it covers is bound to be a permanent work of reference."

A great historian must be a judge and not an advocate. In this respect Cantor can be assigned a high place. In very few instances, if any, does national bias disclose itself. In this regard it would be difficult to name a historian of science who ranks above him.

At the time of the completion of the third volume, Cantor was sixty-nine years old. He knew that he was not equal to the task of preparing a fourth volume. On the other hand, the publishers and the mathematical public desired a continuation of the history. Finally, in 1904, at the Congress in Heidelberg, the plan was matured of bringing out a fourth volume on the cooperative plan. Nine men of different countries (V. Bobynin, A. v. Braunmühl, F. Cajori, S. Günther, V. Kommerell, G. Loria, E. Netto, G. Vivanti, C. R. Wallner) were selected to write certain parts under the direction of Cantor as editor-in-chief. Each collaborator was made responsible for his part. As far as possible each man was expected to follow the mode of presentation adopted in the previous volumes. The men were cautioned not to permit themselves to be dominated by preconceived ideas relating to the subjects or men treated in the history.* The fourth volume carried the history to 1799 , the year of Gauss' doctordissertation.

It is the fate of a scientific man to be succeeded by others who carry his researches to a higher degree of perfection. Fraunhofer mapped the solar spectrum. His work was improved by E. Bequerel in France and J. W. Draper in America, both of whom used photography. Still greater perfection was introduced subsequently by A. Ångström, H. Rowland, and others. Moritz Cantor had a similar experience. The twentieth century set new standards. High as his Vorlesungen towered above other general histories of mathematics (such as those of J. E. Montucla, C. Bossut (1802), A. G. Kästner (1796-1800), J. H. M. Poppe (1828), A. Arneth (1852), F. Hoefer (1874), M. Marie (1883-1888)), it came to be criticized with great severity for lack of accuracy

* For further details see Jahresbericht der deutschen MathematikerVereinigung, vol. 13 (1904), pp. 475-478. 
in minute details. It became evident that the erection of a great and faultless architectural structure must be preceded by the painstaking labors of the quarryman. Gustav Eneström, the editor of the Bibliotheca Mathematica, devoted much of his time for fifteen years to recording corrections to the first three volumes of Cantor's Vorlesungen. The Herculean efforts of Cantor and the extremely penetrating criticisms of Eneström clearly point out two lessons to scholars of today: (1) The need of a more accurate general history of mathematics, prepared on the scale of that of Cantor's Vorlesungen and embracing the historical researches of the last twenty years; (2) the impossibility of this task for any one man. A history of the desired size and accuracy can be secured only by the cooperative effort of many specialists. The mode of preparation of Cantor's fourth volume points the direction to future success.

The prodigious literary activity of Moritz Cantor can be seen also on examination of the volumes of the Zeitschrift für Mathematik und Physik for the years 1856-1898, and the volumes of Allgemeine Deutsche Biographie. The mere enumeration of the titles of his book reviews and of his articles fills twenty-six pages.*

As previously stated, the present writer on May 2, 1915, visited Cantor at Heidelberg, who was then in his eightysixth year. Almost complete blindness had compelled him to stop research. He said he could see the general outline of a person's body, but could not make out the features. He could move about in his house without assistance. His hearing was still good and his mind fairly clear. Neither of us touched upon war issues, except that he, once referred to me as coming from a nominally neutral country. Later in the day I met his son and daughter, who were free in expressing to me the hope that the United States would soon come to observe real neutrality. Cantor made inquiries about certain American and English mathematicians and spoke of special historical researches then in progress in Germany. It was at his suggestion, he said, that K. Bopp undertook the study of Gregory St. Vincent.

\footnotetext{
* See M. Curtze "Verzeichnis der mathematischen Werke, Abhandlungen und Recensionen des Hofrat Professor Dr. Moritz Cantor," in Abhandlungen zur Geschichte der Mathematik, Neuntes Heft, Leipzig, 1899, pp. 625-650.
} 
He spoke of Siegmund Günther as one of his pupils and of the late A. v. Braunmühl as an indirect pupil. The former, he said, had offered himself for service in the war, but was too old to fight. Cantor spoke in high praise of Hermann Hankel, and declared that his early death had been a great loss to mathematics; would that he had lived long enough to have completed his history of mathematics! Hankel, he said, was excellent not only in subject matter but also in the style of presentation. He spoke of his own labors as those of a hewer of timber who with a big axe and with powerful strokes roughly cut the timber to proper form and dimension, but left it for those who follow him to dress, polish and finish. When mention was made of Zeno's arguments on motion, Cantor referred to Paul Tannery's brilliant discussion of that subject. He spoke of Caspar Wessel's noted paper on imaginaries as having been completely neglected for about a century, notwithstanding the fact that Wessel's name as well as the title of his paper were given in so prominent a publication as Poggendorff's Handwörterbuch; H. G. Zeuthen discovered Wessel by accident. Cantor was much surprised that the name Oughtred was pronounced in England "ootred," and said he could not recall for the moment another English word in which "ough" was pronounced "oo." He referred to the mathematical precocity of his young grandson who spoke of the cellar as "minus 1. Stock." He said that in 1900 he discontinued the Abhandlungen zur Geschichte der Mathematik as a department of the Zeitschrift für Mathematik und Physik; nevertheless, only recently, a Vienna scientist had sent him a book for review therein.

He remembered Simon Newcomb at a Congress in Paris delivering an address in the French language when all Germans would have preferred to hear him speak English. At the Congress in Rome an Englishman arose, he said, to thank the King and the Italian mathematicians for the royal reception accorded to members of the Congress. The one who made reply for the Italian government declared his great admiration for the language of William Shakespeare, yet had to confess that his insufficient command of that language prevented him from following the Englishman's speech. A friend nudged the Italian speaker and called his attention to the fact that the Englishman's speech had been delivered in the Italian language. In speaking of Georg Cantor, who 
had shortly before celebrated his seventieth birthday, he said that Georg Cantor's ancestors, as well as his own, came originally from Denmark, that, although he thought he and Georg Cantor were distantly related, the latter did not agree with him. After a dinner which was served in the garden in the open, the writer, having been told that it was Cantor's habit to lie down after the mid-day meal, departed.

University of CaLIFORNia.

\section{SHORTER NOTICES.}

Les Spectres numériques. By Michel Petrovitch, with a preface by EMile Borel. Paris, Gauthier-Villars, 1919.

THE "spectral method" of Professor Petrovitch will be understood through an example taken from the last chapter of his monograph.

Let it be required to determine the coefficients in the development of $(1+z)^{6}$. We have

$$
(1.01)^{6}=1.061520150601 \text {, }
$$

and the binomial coefficients sought appear in the decimal above, some of the coefficients being separated by zeros.

It is clear that a similar method can be used to determine any finite set of positive integers, if the integers are the coefficients in the development of a known rational integral function, and that generalizations to infinite sequences of integers are possible.

Professor Petrovitch calls the decimal above a "spectrum" of the function $(1+z)^{6}$, comparing the binomial coefficients to the colored portions of the spectrum, and the zeros to the dark portions. The book, up to the last chapter, is given up to a discussion of methods for associating "spectra" with different classes of functions.

In spite of the amiable preface of Borel, nothing will be found in the work to make one feel that the author has a point of view which is likely to lead to fruitful developments. Professor Petrovitch has certain speculations, but they are not of enough merit to warrant this address to the mathematical public. 